\title{
MERETAS KESETARAAN PERAN PUBLIK PEREMPUAN
}

\author{
Musram Doso \\ Sekolah Tinggi Ilmu Syariah Darul Falah Bondowoso \\ Email : musramdosodafa@gmail.com
}

\begin{abstract}
Abstrak
Manusia dengan jenis laki-laki dan perempuan seharusnya dilihat dengan merujuk kepada kompetensi dan kapabilitas skillnya bukan personal biologisnya. Struktur biologis manusia adalah kodrati. Jika manusia masih mempersoalkan perbedaan ini yang kemudian mengimbas kepada ketimpangan peran sosial publik diantara salah satu jenis itu, maka dapat dikatakan bahwa ia merupakan bagian dari misigonis patriarkhal. Karena itulah harus ada diantara kita yang berani menyuarakan dan menyadarkan bahwa diciptakannya kedua jenis manusia itu ada pesan implisit ilahiyah yakni saling berbagi peran.
\end{abstract}

Kata Kunci : Kodrati, Ilahiyah, Gender

\section{A. PENDAHULUAN}

Sejak tiga dasa warsa yang lalu, utamanya sepuluh tahun terakhir, kata gender telah memasuki perbendaharaan di setiap diskusi dan tulisan sekitar perubahan sosial dan pembangunan di Dunia ketiga. Demikian juga tentang Indonesia, hempir semua uraian tentang program pengembangan masyarakat maupun pembangunan di kalangan organisasi non-pemerintah memperbincangkan masalah gender. Pada semua lini program yang dilakukan, perspektif gender menjadi suatu yang tak sapat dinafikan. Perspektif gender' ini pun kemudian muncul sebagai sebuah paradigma baru dalam warna kehidupan publik, di media massa, lapangan kerja bahkan masuk ke dalam wilayah rumah tangga.

Karena desakan dari lembaga non pemerintah untuk selalu mensyaratkan adanya sensitifitas gender dalam semua program pengembangan masyarakat, maka mau tidak mau pemeruntah juga berupaya untuk menjadikan keadilan gender sebagai mainstream dalam semua penetapan (juga proses pembuatan) kebijakan yang di ambilnya. 
'Perspektif gender' menjadi prasyarat utama didalamnya - walau dalam banyak kasus hal ini justru tampak 'mengganggu', karena betapapun revolusionernya sebuah ideologi, ketika ia telah 'menegara' maka ia akan lumpuh oleh tabiat kekuasaan yang disandang negara.

\section{B. PERAN DOMESTIK DAN PUBLIK GENDER}

Kehadiran gender pertama-tama dipahami sebagai sebuah penjelasan terhadap perdebatan panjang tentang siapakah sesungguhnya laki-laki dan perempuan itu. Pertanyaan ini penting untuk dijawab karena kesalahan mendefinisikan laki-laki dan perempuan inilah yang kemudian membawa pada pembedaan peran, yang selama ini ditemui menjadi sumber perlakuan yang tidak adil. Laki-laki dipandang telah melakukan dominasi atas perempuan karena kelaki-lakiannya. Alasannya, diantaranya adalah secara kodrati ia diberi bentuk fisik yang lebih kuat daripada perempuan, sehingga dalam pembagian peran dan fungsi yang diemban masing-masing juga bermula dari analisis ini.

Laki-laki sering ditampilkan sebagai seorang yang besar, esertif dan dominan; sementara perempuan sering digambarkan sebagai sosok yang lembut, tidak asertif dan cenderung mengalah. ${ }^{1}$ Maka perbedaan semacam ini juga membawa pada pengkotakkotakan wilayah kerja bagi keduanya.

Pembedaan peran sosial laki-laki dan perempuan seringkali mencari pembenaran melalui perbedaan biologis laki-laki dan perempuan. Secara biologis, laki-laki dan perempuan memiliki alat dan fungsi reproduksi yang berbeda. Perbedaan ini kemudian melhirkan perbedaan peran laki-laki dan perempuan dalam masyarakat. Karena perempuan yang hamil, melahirkan dan menyusui (reproduksi biologis), maka perempuan diapndang sudah seharusnya bertanggungjawab terhadap pengsuhan anak (reproduksi sosial) dan selanjutnya melebar ke seluruh hal di lingkup domestik. Sementara itu, laki-laki dipandang sebagai pihak yang bertanggung jawab "menanggung" perempuan (dan anak-anak), sehingga tempat laki-laki adalah di sektor publik.

\footnotetext{
${ }^{1}$ Ridjal, Fauzi, dkk. Dinamika Gerakan Perempuan di Indonesia, Tiara Wacana, Yogyakarta, 1993. Hlm 29.
} 
Dikotomi publik-domestik ini secara teoritis seharusnya tidak menjadi masalah baik bagi laki-laki maupun perempuan. Namun pada tingkat praktis, dikotomi teersebut melahitrkan kerugian dan ketidakadilan bagi peempuan. Pertama, dunia publik, adalah dunia yang jelas menetapkan sejumlah peraturan, dengan menggunakan ukuran-ukuran rasional. Sementara itu, dunia domestik tidak memiliki aturan yang baku, dianggap "alamiah", dan cenderung emosional. Sesuatu yang berlangsung di lingkup domestik dianggap seperti apa adanya. ${ }^{2}$ Pemikiran tersebut mengakibatkan masalah-masalah yang muncul dalam dunia domestik tidak dianggap masalah dan tidak dianggap penting. Contohnya kekerasan dalam rumah tangga seringkali tidak muncul ke permukaan. Jika persoalan tersebut mencuat ke permukaan, seingkali masalah tersebut dianggap "masalah suami-istri" atau maslah intern keluarga. Karenanya masalah tersebut cukup diselesaikan di tingkat keluarga. Kedua, bidang domestik tidak mendapatkan penghargaan yang memadai seperti halnya bidang publik. ${ }^{3}$ Meskipun ibu rumah tangga seringkali diibaratkan "ratu" rumah tangga, pekerjaan rumah tangga (domestik) adalah pekerjaan "mulia", namun dalam kenyataan puja puji tersebut lebih merupakan hiasan bibir belaka dan tidak berkolerasi dengan penghargaan rill terhadap bidang domestik. Hal ini diindikasikan dengan kecendrungan keengganan laki-laki untuk terlibat dalam bidang domestik. Bahkan menabukan pertisipasi laki-laki dalam bidang domestik. , dikotomi publik-domestik, dianggap "kodrat" sesuatu yang sudah baku dan tidak bisa diubah. Seluruh komponen masyarakat (keluarga, lembaga pendidikan, media massa) memperkuat anggapan tersebut dengan cara langsung atau tidak langsung mensosialisasikan bahwa tugas perempuan adalah dilingkup domestik, sementara tugas laki-laki adalah dilingkup publik.

Ketika persoalan domestik-publik telah menjadi sedemikian akut, hal ini dapat menjadi sumber manifestasi ketidakadilan gender seperti berikut; ${ }^{4}$

a. Marginalisasi; Perempuan dipinggirkan/disingkirikan dari fungsi-fungsi tertentu, khususnya yang bersifat memimpin dan membuat keputusan.

\footnotetext{
2 Arivia, Gadis, 1999, Kekuatan dan Kekuasaan Kaum Ibu, dalam Suara Ibu Peduli, 1999, Catatan perjalan Suara Ibu Peduli, Yayasan Jurnal Perempuan, Jakarta. HIm 8.

${ }^{3}$ Ibid.

${ }^{4}$ Lebih lanjut tentang penjelasan ini, lihat: Faqih, Mansour, Menggeser Konsepsi Gender dan Transformasi Sosial, Pustaka Pelajar, Yogyakarta, 1996.
} 
b. Subordinasi; Perempuan dianggap tidak penting, diposisikan sebagai manusia nomor dua, dinilai lebih rendah daripada laki-laki, dilihat hanya sebagai pelengkap dan bukan subjek.

c. Stereotype; Pembagian tugas, tanggung jawab, serta peran dalam masyarakat berdasarkan pada jenis kelamin atau kepantasan. Hal ini dapat kita lihat pasa suatu kondisi pernikahan, biasanya pekerjaan wanita-lah yang dikorbankan. Wanita harus tingga di rumah untuk mendidik anak dsb. hanya sekedar karena dia wanita.

d. Beban Ganda; Perempuan yang bekerja di sektor publik masih harus dibebani tugas dan tanggung jawab pekerjaan rumah/domestik. Contohnya, biasanya kalaupun wanita sudah bekerja di luar, ketika pulang kantor masih harus menyediakan makanan buat suaminya, mengasuh anak, mencuci, dan sebagainya.

e. Kekerasan terhadap peempuan; Tindakan kekerasan yang disebabkan karena pendangan bahwa perempuan itu lemah, sehingga dijadikan objek tindak kekerasan, baik kekerasan fisik maupun psikis.

\section{URGENSI KESETARAAN PERAN GENDER}

Perbedaan gender sebenarnya tidak bermasalah apabila dia tidak mendatangkan ketidakadilan gender. Dalam melakukan pekerjaan apapun misalnya perempuan harus memiliki kebebasan untuk memilih. Keputusan yang dipilihnya harus merupakan keputusan yang bebas dari faktor pengkondisian atau pembiasaan. Bila semua ini dapat berjalan baik, perbedaan gender tidak akan mendatangkan masalah.

Namun sejarah panjang perbedaan gender (gender differences) antara manusia yang berjanis kelamin laki-laki dan perempuan terkonstruksi melalui proses yang begitu rumit dan panjang. Perbedaan jenis kelamin yang mengakibatkan terwujudnya ketidakadilan gender diakibatkan oleh sosialisasi, dan kontruksi secara sosial, kultural, melalui ajaran keagamaan dan juga oleh kekuasan negara. ${ }^{5}$

Upaya memperjuangkan gender kemudian menjadi perjuangan yang amat berat, karena di dalamnya terlibat emosi kita masing-masing; apalagi masalah ketidakadilan gender telah merambah spektrum yang amat luas. Karenanya pemecahan dari persoalan ini harus dilakukan secara serempak, bersama dan dengan dasar visi yang sama, yakni

\footnotetext{
${ }^{5}$ Hamidah, Luluk Nur (Pengantar), Perempuan di Garis Depan, PB. PMII Korp Putri, Jakarta Nopember 2000, hlm. 133
} 
membebaskan kaum perempuan dari belenggu penjajahan sistem sosial yang dirancang (secara sengaja maupun tidak) oleh teks agama, tradisi dan kebudayaan, kapitalisme dan kekuasan negara.

Di sisi lain, perjuangan untuk menegakkan keadilan gender ini terkait erat denga gerakan feminisme; sementara feminsme sendiri masih menyimpan banyak persoalan yang belum tuntas. Feminisme, di Indoenesia khususnya, masih banyak dianggap sebagai gerakan yang hanyua sekedar mengikuti garakan feminisme barat, yang mana mereka memiliki konteksnya sendiri.

Alasan lainnnya yang tidak kalah seriusnya adalah berkisar pada: 1) Istilah feminisme itu sendiri, 2) anggapan bahwa feminisme itu adalah sebuah aliran monolitik, dan 3) terlepas dari konteks historisnya. ${ }^{6}$ Feminisme juga tidak seperti isme yang lain, ia tidak memiliki dasar konseptual dan teoritisnya dari suatu rumusan teori tunggal. Oleh karena itu tidak ada definisi abstrak yang khususntentang feminisme yang dapat diterapkan bagi semua gerakan perempuan pada segenap waktu. Dengan dmeikian, definisinya dapat - dan pada kenyataannya memang - berubah-ubah, karena feminisme bberdasarkan atas realitas kultural dan kenyataan sejarah yang kongkrit, maupun atas tingkatan-tingkatan kesadaran persepsi serta tindakan. ${ }^{7}$

Sementara feminisme dengan definisi yang sangat longgar ini memunculkan pertanyaan, Tidaklah sebaiknya ia memiliki landasan epistimolgis dan metodologis sebagai sebuah teori tunggal, sehingga tafsir gerakan yang dilakukan tidak terhadapnya tidak menyimpang dari arah epistimnya. Namun sebetulnya jika ditilik lebih lanjut, bahwa kelonggaran seperti ini justru dapat menjadikannya sebagai gerakan yang fleksibel. Sebagaimana layaknya sebuah konsep makro, ia dapat diterjemahkan dan dibumikan sesuai dengan konteks ruang dan waktu dimana ia sedang berkembang.

Sebab, feminisme pada dasarnya bukan hanya sebatas pada persoalan gender yang sempit, karena ia tidak lain merupakan sebuah gerakan kemanusiaan. Tepatnya, ia hanya ingin mendekati persolan dasar kehidupan bahwa ada hak-hak kemanusiaan yang perlu diperjuangkan kerika hak-hak tersbut terdistorsi oleh kerimpangan gender. Dan bukan saja perempuan yang m,emiliki kesdaran atas realitas ini, namun laki-laki pun,

\footnotetext{
${ }^{6}$ Awuy, Tommy F, Wacana, Tragedi dan Dekontruksi Kebudayaan, Jentera, Jakarta, 1995, hlm. 87.

${ }^{7}$ Bhasin, kamla dan Nighat Said Khan, Feminisme dan Relevansinya, Gramesia Pustaka Utama, jakarta, cet.II 1999, hlm. 5.
} 
ytentu saja dapat memiliki kesadaran yang sama dan memiliki hakyang sama pula untuk memperjuangkan hak-hak kemanusiaan.

\section{PENUTUP}

Kita yakin bahwa apa yang telah diciptakan tuhan pasti ada tujuan dan manfaatnya masing-masing, termasuk dalam penciptaan manusia dengan jenis kelaminnya. Tuhan tidak mungkin memberikan hak istimewa bagi salah satu jenis manusia. Telah menjadi kodrat manusia bahwa mempunyai kelebihan dan kekurangan. Diciptakannya kedua jenis dengan perannya masing-masing yang melekat sejak lahir adalah untuk saling menyempurnakan. Ada pesan ketuhanan yang tak kasat mata, dan kebanyakan manusia mengabaikannya ketika manusia diciptakan dengan dua jenis yaitu agar manusia berbagi peran dalam menjalani tugasnya sebagai khalifah fil ardh. Apabila dalam praktik kehidupan ada satu jenis manusia ciptaan Allah yang terendahkan, terabaikan, terpinggirkan perannya. Maka ia secara tidak langsung telah melawan pesat tersembunyi dari Allah Swt. 


\section{DAFTAR PUSTAKA}

Ridjal, Fauzi, dkk. Dinamika Gerakan Perempuan di Indonesia, Tiara Wacana, Yogyakarta, 1993.

Arivia, Gadis, 1999, Kekuatan dan Kekuasaan Kaum Ibu, dalam Suara Ibu Peduli, 1999, Catatan perjalan Suara Ibu Peduli, Yayasan Jurnal Perempuan, Jakarta.

Faqih, Mansour, Menggeser Konsepsi Gender dan Transformasi Sosial, Pustaka Pelajar, Yogyakarta, 1996.

Hamidah, Luluk Nur (Pengantar), Perempuan di Garis Depan, PB. PMII Korp Putri, Jakarta Nopember 2000.

Awuy, Tommy F, Wacana, Tragedi dan Dekontruksi Kebudayaan, Jentera, Jakarta, 1995.

Bhasin, Kamla dan Nighat Said Khan, Feminisme dan Relevansinya, Gramesia Pustaka Utama, Jakarta, cet.II 1999. 